\title{
The Effects of a Community Empowerment Program on Community Awareness and Capacity among Stakeholders in Diabetes Prevention in Buddhist Monks
}

\author{
Khanitta Wisitcharoen $^{1^{*}}$, Waraporn Boonchieng ${ }^{2}$, \\ Thanaruk Suwanprapisa ${ }^{2}$ and Prapim Buddhirakkul ${ }^{2}$ \\ ${ }^{I}$ Faculty of Nursing, Srinakarintawirot University, Nakhonnayok 26120, Thailand \\ ${ }^{2}$ Faculty of Nursing, Chiang Mai University, Chiang Mai 50200, Thailand \\ ${ }^{*}$ Corresponding author. E-mail: yimyim_wisit@hotmail.com \\ https://doi.org/10.12982/CMUJASR.2016.0008
}

\section{ABSTRACT}

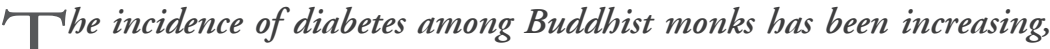

1 because monks cannot exercise in the same way as the general population and depend on the community for their food. This study is a quasi-experimental design; pretest - posttest control group design. The aim was to examine the effects of a community empowerment program on community awareness and capacity among stakeholders in diabetes prevention in Buddhist monks. Sixty-seven participants who met the inclusion criteria were divided into two groups: participating in the community empowerment program $(n=34)$ and not participating $(n=$ 33). The instruments used for data collection were a Demographic Data Form, the Community Awareness of Diabetes Prevention among Buddhist Monks Scale (CADS) and the Community Capacity in Diabetes Prevention among Buddhist Monks Scale (CCDPS). All instruments were tested for validity and reliability before use. Results were analyzed between the experimental and control group at each point of measurement. Descriptive statistics and the Mann-Whitney U test were used to analyze the data. Results showed the mean of all scores for CADS and CCDPS of the group who participated in community empowerment program at the end of the program and three months after the end of the program were significantly higher than those not participating in the program $(p<.01)$. The community empowerment program, therefore, is a valid tool to increase community awareness and capacity in diabetes prevention among Buddhist monks. This program is recommended for use in other communities where the same situation arises.

Keywords: Community empowerment program, Community awareness and capacity, Diabetes, Buddhist monks 


\section{INTRODUCTION}

In Thai communities, Buddhist monks have a very close relationship to the people. This is partly because the monks are locals, and often come from the communities they serve, with relatives living nearby (Buates et al., 2010). In addition, Buddhist monks provide spiritual support for the people and their community, important to Thais and Thai culture (Kuramasuwan et al., 2013; \& Larpthananon, 2014). In order for Buddhist monks to fulfill their obligations, they must be in good health and have a high level of wellbeing. However, a recent study showed the prevalence of Buddhist monks in Thailand with pre-diabetes was $4.1 \%$ and diabetes was $6.9 \%$ (Larpthananon, 2013). In addition, $45.1 \%$ of monks were overweight (Larpthananon, 2013), which is a risk factor for type 2 diabetes.

A review of relevant literature indicated that Buddhist monks were less likely to consume healthy food and perform proper exercise (Larpthananon, 2014), as they are not permitted to exercise in the same way as the general population. The Vinaya Pitaka (the basket of the Buddhist discipline) has strict guidance regarding exercise in public (Srimanee et al., 2013). Lord of Buddha allowed alms-gathering (walking for food offerings in the morning), sweeping the temple court and cleaning their lodge (Kuti), and walking meditation (Buates et al., 2010; Kuramasuwan et al., 2013; Larpthananon, 2013) as the only recommended physical activities for Buddhist monks. Moreover, most Buddhist monks depend on food offerings for their diet, so they have little control over what they eat, depending on what the community prepares instead; this is linked to the unhealthy eating habits of monks. Srimanee et al. (2013) revealed that Buddhist monks consumed food that is calorie rich, perhaps linked to their lack of choice and restrictions against preparing their own food. People often offer food that is either relatively easy to prepare or commercially available (Srimanee et al., 2013; Angkatavanich et al., 2014). Curry and deep-fried foods are most common in almsgiving sets; these sets usually contain high caloric foods, rich in coconut milk or oil from the preparation process (Angkatavanich et al., 2014). In addition, people select food that they believe will bring good fortune, or a dish their ancestors liked; as a result, most of the foods offered to the monks are more likely to be high in calories, salt, and sugar and low in protein (Kuramasuwan et al., 2013; Srimanee et al., 2013; Angkatavanich et al., 2016).

As the health of Buddhist monks depends in part on the community they serve, the community should informally support and help promote their good health. Particularly given the role of food offerings in the monks' diets, it is important for the community to be aware of the monks' daily physical activities and nutritional intake. With the role of diet and exercise in diabetes prevention, raising community awareness and building community capacity to improve the health of Buddhist monk would be of great value, for both the monks and communities they serve. 
Strategies are required to enhance community awareness and community capacity for diabetes prevention among Buddhist monks; however, the only study to research this issue to date, Angkatavanich (2012), was from the perspective of the monks themselves, rather than from the role the community can play.

Community empowerment is an effective strategy in raising community awareness and building community capacity in the control of diabetes (Braun et al., 2003; \& Ramsden et al., 2006). Rissel (1994) described effective community empowerment as a process whereby people, organizations, and communities gain mastery over their lives. The community empowerment process includes: 1) personal development, 2) mutual support groups, 3) issue identification and campaigns/ organization, 4) participation in organization/coalition advocacy, and 5) collective political and social action. However, its efficacy in assisting diabetes prevention among Buddhist monks has not yet been analyzed, particularly in Thailand. The objective of this study, therefore, was to examine the effects of a community empowerment program on community awareness and community capacity among stakeholders in working toward diabetes prevention in Buddhist monks by using a pretest-posttest control group design.

\section{METHODOLOGY}

\section{Study approval}

The procedures of this study followed ethical principles and were approved by the Research Ethics
Committee of the Faculty of Nursing, Chiang Mai University.

\section{Study design}

This study applied a quasi-experimental design, pretest-posttest control group design. One of the groups participated in a community empowerment program (experimental) and another group did not (control). Data was collected over a five-month period from February through June 2016.

\section{Participants}

The participants in this study were divided into five main groups of stakeholders - lay leaders (temple 'guides'), healthcare providers, lay people, village health volunteers, and community leaders - from the San Sai Mahawong and Saraphi Sub-districts in Saraphi District, Chiang Mai Province, Thailand. The participants were selected from each sub-district in proportion to the number of temples in the area. To be included in the study, all participants had to meet the following inclusion criteria: worked in the study area for at least six months, could read and speak Thai, and committed to participating in the entire study. In addition, participants in each group had to meet the following additional criteria:

- Lay leaders (temple 'guides') prepared and offered food to Buddhist monks and were respected members of the community.

- Healthcare providers - were respected members of the community.

- Lay people - prepared and offered food daily to Buddhist monks. 
- Village health volunteers - were responsible for diabetes prevention.

- Community leaders (village headmen) - were respected members of the community.

Participants were excluded if they were unable to complete the questionnaires or did not participate in the entire study.

\section{Sample size}

The sample size was calculated using the sample size determinate formula for repeated measurement analysis (Viwatwongkasem, 1994). An effect size was calculated based on Yamaoka \& Tango (2005), who evaluated the efficacy of lifestyle education for preventing type 2 diabetes in individuals at high risk by metaanalysis of randomized controlled trials using the formula suggested by Polit $\&$ Beck (2004). The effect size was 0.63 . To ensure an adequate sample size, an attrition rate was included in the recruitment plan based on similar community-based studies, such as the Female Community Health Volunteer (FCHV) Programme in Nepal, with an attrition rate of less than 5\% (Glenton et al., 2010). We incorporated an attrition rate of $5 \%$ into our minimum sample size, calculated at 66 participants (33 each in the intervention and control groups).

The sample was recruited based on multi-stage sampling. One district out of twenty-five in Chiang Mai Province was selected; then two sub-districts were selected - one as the experimental (or intervention) group and one as the control group. San Sai Mahawong Sub-district was selected as the experimental group and Saraphi Sub-district as the control group. After that, the participants (lay leaders, healthcare providers, lay people, village health volunteers, and community leaders) were selected in accordance to the number of temples in the area. All members of the first two groups: lay leaders and healthcare providers were selected, because they were few in number. Participants from the remaining three groups (lay people, village health volunteers, and community leaders) were selected using simple random sampling, with the total selected number from each group equaling the number of temples in the community. For example, if the community had eight temples, we selected eight lay people, eight village health volunteers, and eight community leaders. Based on this sampling method, the study included 67 participants - 34 from San Sai Mahawong and 33 from Saraphi.

\section{Instruments}

Demographic data form. A demographic data form was designed to obtain information on participants. Individual data included age, gender, education, occupation, family income, and community. In addition, the social capital of each community was determined. Social capital is "the network of relationships among people who live and work in that society (tangible and intangible), the relationships creating the values of the social structure and facilitates the actions of the 
people within that structure" (Seibert et al., 2001).

The community awareness of diabetes prevention among Buddhist monks scale (CADS). No existing instruments for measuring community awareness were a good fit for Thai culture and the topic of this study, so we developed CADS based on diabetes awareness factors cited in Al-Khawaldeh and Al-Jaradeen (2013), then modified the scale based on a literature review. CADS was divided into four main categories: diabetes knowledge and its prevalence (5 questions); diabetes risk factors (5 questions); diabetes complications (4 questions), and the community role in diabetes prevention among Buddhist monks (6 questions). The questions used a three-point Likert scale: (1) disagree, (2) neutral, and (3) agree. The possible total score of the CADS ranged from 0 to 60 and allowed direct comparison between the start and end of the program, as well as between the two communities. The Content Validity Index (CVI) was 0.83 . Internal reliability of the CADS was 0.70 , an acceptable level for a newly designed instrument (Burns \& Grove, 2005).

The community capacity in diabetes prevention among Buddhist monks scale (CCDPS). As with CADS, no existing instruments addressed the needs of this study in the Thai context, so we developed the CCDPS from the principle of community capacity (Africare, 2007), together with in- formation from a literature review. CCDPS instrument consisted of 30 self-reported items, with 10 capacitybuilding variables to assess community capacity: community organization (3 questions); community participation (2 questions); transparency and good management (3 questions); good internal functioning of the organization (5 questions); capacity to analyze and plan (2 questions); capacity to take action (4 questions); community capacity to analyze and manage risks (3 questions); community capacity to manage risks associated with diabetes (4 questions); communication and exchange with outsiders (2 questions), and individual capacity (3 questions). The response of each item used a four-point rating scale: $(0)=$ nil; $(1)=$ fair $(<25 \%)$; $(2)$ = satisfactory $(25 \%$ $50 \%) ;(3)=$ excellent $(>50 \%)$. The total score for the community capacity ranged from 0 to 90 and allowed direct comparison between the start and end of the program, as well as between the two communities. The CVI was 0.80 and the reliability coefficient was 0.83 , which were acceptable (Burns \& Grove, 2005).

\section{Intervention description}

The program was developed based on community empowerment as described by Rissel (1994). The intervention was an educational program of eight weeks duration that required a three- to six-hour session every week (Table 1). 
Table 1. Community empowerment program.

\begin{tabular}{|c|c|c|c|c|}
\hline $\begin{array}{l}\text { Community } \\
\text { empowerment }\end{array}$ & Process & $\begin{array}{l}\text { Session/ } \\
\text { week }\end{array}$ & $\begin{array}{l}\text { Method/ } \\
\text { activities }\end{array}$ & Content \\
\hline \multirow[t]{4}{*}{$\begin{array}{l}\text { 1. Personal } \\
\text { development }\end{array}$} & $\begin{array}{l}\text { - Psychologi- } \\
\text { cal empower- } \\
\text { ment }\end{array}$ & $\begin{array}{l}\text { Session } 1 \\
\text { Week } 1 \\
(1 \mathrm{hr} \\
30 \mathrm{~min})\end{array}$ & $\begin{array}{l}\text { - Giving } \\
\text { information }\end{array}$ & $\begin{array}{l}\text { - Provide participants with } \\
\text { program information and } \\
\text { procedures for data collection }\end{array}$ \\
\hline & $\begin{array}{l}\text { - Increase } \\
\text { community } \\
\text { awareness }\end{array}$ & & $\begin{array}{l}\text { - Baseline } \\
\text { measurement }\end{array}$ & $\begin{array}{l}\text { - Measure community } \\
\text { awareness and community } \\
\text { capacity }\end{array}$ \\
\hline & & $\begin{array}{l}\text { Week } 2 \\
(3 \mathrm{hr})\end{array}$ & $\begin{array}{l}\text { - Health } \\
\text { education } \\
\text { - Discussion }\end{array}$ & $\begin{array}{l}\text { - The severity, impact, risk } \\
\text { factors, signs and symptoms, } \\
\text { treatment of diabetes } \\
\text { - Diabetes prevention } \\
\text { - Diabetes situation and } \\
\text { risk factors among } \\
\text { Buddhist monks }\end{array}$ \\
\hline & & $\begin{array}{l}\text { Week } 3 \\
\text { (3 hr) }\end{array}$ & $\begin{array}{l}\text { - Health } \\
\text { education } \\
\text { - Discussion } \\
\text { - Demonstration }\end{array}$ & $\begin{array}{l}\text { - Provide knowledge and } \\
\text { skills to choose healthy } \\
\text { food, healthy nutrition and } \\
\text { the need for a healthy bowl } \\
\text { for food offerings and } \\
\text { appropriate physical activity } \\
\text { for Buddhist monks } \\
\text { - Group discussion eliciting } \\
\text { participants' experiences } \\
\text { about providing food } \\
\text { offerings to Buddhist monks } \\
\text { - How to promote healthy } \\
\text { eating } \\
\text { - Healthy food offerings for } \\
\text { Buddhist monks } \\
\text { - Physical activity among } \\
\text { Buddhist monks }\end{array}$ \\
\hline $\begin{array}{l}\text { 2. Mutual } \\
\text { support } \\
\text { group }\end{array}$ & $\begin{array}{l}\text { - Sense of } \\
\text { community } \\
\text { - Community } \\
\text { capacity } \\
\text { building }\end{array}$ & $\begin{array}{c}\text { Session } 2 \\
\text { Week } 4 \\
(3 \mathrm{hr})\end{array}$ & $\begin{array}{l}\text { - Health } \\
\text { education and } \\
\text { group } \\
\text { discussion } \\
\text { - Round Table } \\
\text { group discussion }\end{array}$ & $\begin{array}{l}\text { - Provide information about } \\
\text { the role of community in } \\
\text { diabetes prevention among } \\
\text { Buddhist monks } \\
\text { - Community agreement } \\
\text { for diabetes prevention } \\
\text { among Buddhist monks }\end{array}$ \\
\hline $\begin{array}{l}\text { 3. Issue } \\
\text { identification } \\
\text { and cam- } \\
\text { paigns/ } \\
\text { organization }\end{array}$ & $\begin{array}{l}\text { - Sense of } \\
\text { community } \\
\text { - Community } \\
\text { capacity } \\
\text { building }\end{array}$ & $\begin{array}{l}\text { Session } 3 \\
\text { Week } 5 \\
(3 \mathrm{hr})\end{array}$ & $\begin{array}{l}\text { - Photo-voice } \\
\text { method }\end{array}$ & $\begin{array}{l}\text { - Take photos about food } \\
\text { in food offerings and } \\
\text { physical activities among } \\
\text { Buddhist monks } \\
\text { - Discuss the photos }\end{array}$ \\
\hline
\end{tabular}




\begin{tabular}{|c|c|c|c|c|}
\hline $\begin{array}{l}\text { Community } \\
\text { empowerment }\end{array}$ & Process & $\begin{array}{l}\text { Session/ } \\
\text { week }\end{array}$ & $\begin{array}{l}\text { Method/ } \\
\text { activities }\end{array}$ & Content \\
\hline $\begin{array}{l}\text { 4. Participa- } \\
\text { tion in } \\
\text { organization/ } \\
\text { coalition } \\
\text { advocacy }\end{array}$ & $\begin{array}{l}\text { - Sense of } \\
\text { community } \\
\text { - Community } \\
\text { capacity } \\
\text { building }\end{array}$ & $\begin{array}{l}\text { Week } 5 \\
(3 \mathrm{hr})\end{array}$ & $\begin{array}{l}\text { - Social network } \\
\text { - Discussion }\end{array}$ & $\begin{array}{l}\text { - Strengthen the existing } \\
\text { local community organiza- } \\
\text { tion and their functionality } \\
\text { in diabetes prevention } \\
\text { among Buddhist monks } \\
\text { - Provide support for } \\
\text { participants to use mass } \\
\text { media from the 'Healthy } \\
\text { monks, healthy nutrition } \\
\text { project' }\end{array}$ \\
\hline \multirow[t]{3}{*}{$\begin{array}{l}\text { 5. Collective } \\
\text { political and } \\
\text { social action }\end{array}$} & $\begin{array}{l}\text { - Sense of } \\
\text { community } \\
\text { - Community } \\
\text { capacity } \\
\text { building }\end{array}$ & $\begin{array}{l}\text { Session } 4 \\
\text { Week } 6 \\
(3-6 \mathrm{hr})\end{array}$ & $\begin{array}{l}\text { - Community } \\
\text { action plan in } \\
\text { diabetes preven- } \\
\text { tion among } \\
\text { Buddhist monks } \\
\text { - Temple visit } \\
\text { by participants } \\
\text { and researcher }\end{array}$ & $\begin{array}{l}\text { - Participants visit } \\
\text { Buddhist monks to set } \\
\text { goals and an action plan for } \\
\text { diabetes prevention. Goals } \\
\text { set with an ethos of } \\
\text { working in collaboration } \\
\text { with the community, and } \\
\text { taking into account the } \\
\text { current health of the } \\
\text { Buddhist monks. } \\
\text { - Participants support } \\
\text { Buddhist monks to follow } \\
\text { their goals and pursue an } \\
\text { action plan for diabetes } \\
\text { prevention. } \\
\text { - Provide information } \\
\text { about diabetes knowledge } \\
\text { and diabetes prevention } \\
\text { - Discuss how to choose } \\
\text { healthy food from food } \\
\text { offerings }\end{array}$ \\
\hline & $\begin{array}{l}\text { - Sense of } \\
\text { community } \\
\text { - Community } \\
\text { capacity } \\
\text { building }\end{array}$ & $\begin{array}{c}\text { Session } 5 \\
\text { Week 7-8 } \\
(3-6 \mathrm{hr})\end{array}$ & $\begin{array}{l}\text { - Motivate } \\
\text { - Promote com- } \\
\text { munity aware- } \\
\text { ness and capacity } \\
\text { in diabetes } \\
\text { prevention } \\
\text { among Buddhist } \\
\text { monks }\end{array}$ & $\begin{array}{l}\text { - Offer and find communi- } \\
\text { ty resources to support } \\
\text { Buddhist monks in lifestyle } \\
\text { modification }\end{array}$ \\
\hline & & $\begin{array}{l}\text { At the end } \\
\text { of the } \\
\text { program } \\
\text { and three } \\
\text { months } \\
\text { after the } \\
\text { end of the } \\
\text { program }\end{array}$ & $\begin{array}{l}\text { Post-test at the } \\
\text { end of the } \\
\text { program and } \\
\text { post-test } 3 \\
\text { months after } \\
\text { the end of the } \\
\text { program }\end{array}$ & $\begin{array}{l}\text { - Measure community } \\
\text { awareness and capacity in } \\
\text { diabetes prevention among } \\
\text { Buddhist monks }\end{array}$ \\
\hline
\end{tabular}




\section{RESULTS}

Demographic characteristics of participants

Sixty-seven participants $(34$ in the experimental group and 33 in the control group) completed the community empowerment program. The demographic characteristics of the participants are presented in Table 2. The demographic data between the experimental and control groups were not significantly different.

Table 2. Demographic characteristics of the experimental and control groups.

\begin{tabular}{|c|c|c|c|}
\hline Demographic characteristics & $\begin{array}{c}\text { Experimental } \\
(\mathrm{n}=34) \\
\mathrm{n}(\%)\end{array}$ & Control & $p$-value \\
\hline Gender & & & $0.133^{\mathrm{c}}$ \\
\hline Male & $15(44.1 \%)$ & $11(33.3 \%)$ & \\
\hline Female & $19(55.9 \%)$ & $22(66.7 \%)$ & \\
\hline Age (yrs) & & & $0.197^{\mathrm{t}}$ \\
\hline Mean (SD) & $54(10.3)$ & $58(8.2)$ & \\
\hline Range & $25-78$ & $30-72$ & \\
\hline Education level & & & $0.499^{c}$ \\
\hline Primary school & $16(47.1 \%)$ & $12(36.4 \%)$ & \\
\hline Secondary / high school & $12(35.3 \%)$ & $11(33.3 \%)$ & \\
\hline Diploma / Bachelor's degree & $6(17.6 \%)$ & $10(30.3 \%)$ & \\
\hline Occupation & & & $0.694^{\mathrm{c}}$ \\
\hline Government official & $3(8.8 \%)$ & $8(24.2 \%)$ & \\
\hline Employee & $5(14.7 \%)$ & $9(27.3 \%)$ & \\
\hline Merchant & $5(14.7 \%)$ & $7(21.2 \%)$ & \\
\hline Farmer & $21(61.8 \%)$ & $9(27.3 \%)$ & \\
\hline \multicolumn{4}{|l|}{ Income (THB/month) } \\
\hline Mean (SD) & $\begin{array}{c}10,085 \\
\text { (THB 7,799) }\end{array}$ & $\begin{array}{c}11,391 \\
\text { (THB 7,759) }\end{array}$ & $0.204^{t}$ \\
\hline
\end{tabular}

Note: $\mathrm{t}=$ independent $\mathrm{t}$-test, $\mathrm{c}=$ chi-square test, USD 1 = THB 35.195 (June 30, 2016; Bank of Thailand).

Community awareness and capacity

The Kolmogorov-Smirnov Test was first used to investigate the effect of the community empowerment program on community awareness and capacity in diabetes prevention among Buddhist monks; however, the distribution of the dependent variables in the experimental and control groups were not normally distributed. Therefore, the Mann-Whitney U test was used. The baseline parameters between the experimental and control groups did not differ significantly for any of the measured variables. After the program, the total CADS score of the experimental group was slightly higher $(p<0.01)$ than the control group, indicating 
that the empowerment program improved overall community awareness, although the only sub-component to show significant improvement was the 'community role in diabetes prevention among Buddhist monks' (Table 3). Three months after the program, none of the variables differed significantly between the two groups.

Table 3. Comparison of community awareness of diabetes prevention among Buddhist monks scale (CADS) between the experimental and control groups.

\begin{tabular}{llll}
\hline \multirow{2}{*}{ Measurement } & \multicolumn{2}{c}{ Mean score (SD) } & Mann- \\
\cline { 2 - 3 } & Whitney & W-value \\
& Experimental & Control & U Value
\end{tabular}

\section{Community awareness}

Diabetes knowledge and its prevalence

\begin{tabular}{lllll} 
Baseline & $12.68(1.45)$ & $13.12(1.19)$ & 473.5 & 0.255 \\
$\begin{array}{l}\text { Post-test at the end of the } \\
\text { program }\end{array}$ & $13.50(1.29)$ & $13.55(1.35)$ & 547.5 & 0.861 \\
$\begin{array}{l}\text { Post-test three months } \\
\text { after the program }\end{array}$ & $14.20(1.09)$ & $14.06(1.06)$ & 506.0 & 0.458 \\
\hline
\end{tabular}

Diabetes risk factors

\begin{tabular}{|c|c|c|c|c|}
\hline Baseline & $12.50(1.91)$ & $12.82(1.72)$ & 526.5 & 0.660 \\
\hline $\begin{array}{l}\text { Post-test at the end of the } \\
\text { program }\end{array}$ & $13.70(1.57)$ & $12.70(2.26)$ & 417.0 & 0.063 \\
\hline $\begin{array}{l}\text { Post-test three months } \\
\text { after the program }\end{array}$ & $13.32(1.59)$ & $12.97(2.27)$ & 544.0 & 0.827 \\
\hline \multicolumn{5}{|l|}{ iabetes complications } \\
\hline Baseline & $10.79(1.07)$ & $11.15(1.03)$ & 443.5 & 0.120 \\
\hline $\begin{array}{l}\text { Post-test at the end of the } \\
\text { program }\end{array}$ & $11.12(1.09)$ & $11.30(1.40)$ & 455.0 & 0.128 \\
\hline $\begin{array}{l}\text { Post-test three months } \\
\text { after the program }\end{array}$ & $11.35(0.98)$ & $11.30(1.36)$ & 511.5 & 0.471 \\
\hline
\end{tabular}

Community role in diabetes prevention among Buddhist monks

\begin{tabular}{|c|c|c|c|c|}
\hline Baseline & $15.76(2.05)$ & $15.58(2.28)$ & 548.5 & 0.873 \\
\hline $\begin{array}{l}\text { Post-test at the end of the } \\
\text { program }\end{array}$ & $\underline{16.82(1.45)}$ & $14.45(2.18)$ & $\underline{216.0}$ & $\underline{0.000}$ \\
\hline $\begin{array}{l}\text { Post-test three months } \\
\text { after the program }\end{array}$ & $16.71(1.77)$ & $15.85(2.46)$ & 464.0 & 0.204 \\
\hline
\end{tabular}




\begin{tabular}{|c|c|c|c|c|}
\hline \multirow{2}{*}{ Measurement } & \multicolumn{2}{|c|}{ Mean score (SD) } & \multirow{2}{*}{$\begin{array}{l}\text { Mann- } \\
\text { Whitney } \\
\text { U Value }\end{array}$} & \multirow{2}{*}{$p$-value } \\
\hline & Experimental & Control & & \\
\hline \multicolumn{5}{|c|}{ Total community awareness score } \\
\hline Baseline & $51.74(4.42)$ & $52.67(3.71)$ & 505.0 & 0.481 \\
\hline $\begin{array}{l}\text { Post-test at the end of the } \\
\text { program }\end{array}$ & $55.15(4.48)$ & $52.00(5.43)$ & 317.5 & $\underline{0.002}$ \\
\hline $\begin{array}{l}\text { Post-test three months } \\
\text { after the program }\end{array}$ & $55.59(4.11)$ & $54.18(6.28)$ & 512.5 & 0.541 \\
\hline
\end{tabular}

Note: Underline indicates measurements with significant differences.

For Community Capacity in Di- program and three months after the abetes Prevention Among Buddhist program, the total community caMonks Scale (CCDPS), the baseline pacity was significantly higher for the parameters between the experimen- experimental group than the control tal and control groups did not differ group, as well as with several of the significantly for any of the measured sub-components. (Table 4). variables. However, at the end of the

Table 4. Comparison of community capacity in diabetes prevention among Buddhist monks scale (CCDPS) between the experimental and control groups.

\begin{tabular}{|c|c|c|c|c|}
\hline \multirow{2}{*}{ Measurement } & \multicolumn{2}{|c|}{$\begin{array}{l}\text { Mean score } \\
\text { (mean rank) }\end{array}$} & \multirow{2}{*}{$\begin{array}{l}\text { Mann- } \\
\text { Whitney } \\
\text { U Value }\end{array}$} & \multirow{2}{*}{$p$-value } \\
\hline & Experimental & Control & & \\
\hline \multicolumn{5}{|l|}{ Community organization } \\
\hline Baseline & $0.79(0.81)$ & $0.85(0.83)$ & 537.0 & 0.746 \\
\hline $\begin{array}{l}\text { Post-test at the end of the } \\
\text { program }\end{array}$ & $3.88(1.75)$ & $1.55(0.94)$ & 106.0 & 0.000 \\
\hline $\begin{array}{l}\text { Post-test three months after } \\
\text { the program }\end{array}$ & $5.03(2.87)$ & $1.55(0.91)$ & 113.5 & 0.000 \\
\hline \multicolumn{5}{|l|}{ Community participation } \\
\hline Baseline & $0.08(0.29)$ & $0.09(0.52)$ & 530.0 & 0.344 \\
\hline $\begin{array}{l}\text { Post-test at the end of the } \\
\text { program }\end{array}$ & $2.94(1.01)$ & $0.12(0.55)$ & 18.50 & 0.000 \\
\hline $\begin{array}{l}\text { Post-test three months } \\
\text { after the program }\end{array}$ & $2.91(1.83)$ & $0.12(0.55)$ & 71.5 & 0.000 \\
\hline
\end{tabular}




\begin{tabular}{|c|c|c|c|c|}
\hline \multirow[t]{2}{*}{ Measurement } & \multicolumn{2}{|c|}{$\begin{array}{l}\text { Mean score } \\
(\text { mean rank) }\end{array}$} & \multirow{2}{*}{$\begin{array}{l}\text { Mann- } \\
\text { Whitney } \\
\text { U Value }\end{array}$} & \multirow[t]{2}{*}{$p$-value } \\
\hline & Experimental & Control & & \\
\hline \multicolumn{5}{|c|}{ Transparency and good management } \\
\hline Baseline & $0.24(0.50)$ & $0.33(0.74)$ & 550.0 & 0.846 \\
\hline $\begin{array}{l}\text { Post-test at the end of the } \\
\text { program }\end{array}$ & $3.71(1.85)$ & $0.42(0.83)$ & 35.0 & 0.000 \\
\hline $\begin{array}{l}\text { Post-test three months } \\
\text { after the program }\end{array}$ & $4.03(1.83)$ & $0.48(0.87)$ & 29.0 & 0.000 \\
\hline \multicolumn{5}{|c|}{ Good internal functioning of the organization } \\
\hline Baseline & $1.88(2.31)$ & $2.36(1.97)$ & 461.0 & 0.192 \\
\hline $\begin{array}{l}\text { Post-test at the end of the } \\
\text { program }\end{array}$ & $6.65(2.65)$ & $2.27(2.02)$ & 116.0 & 0.000 \\
\hline $\begin{array}{l}\text { Post-test three months } \\
\text { after the program }\end{array}$ & $8.29(3.25)$ & $2.15(2.06)$ & 60.5 & 0.000 \\
\hline \multicolumn{5}{|l|}{ Capacity to analyze and plan } \\
\hline Baseline & $0.24(0.74)$ & $0.18(0.58)$ & 534.0 & 0.548 \\
\hline $\begin{array}{l}\text { Post-test at the end of the } \\
\text { program }\end{array}$ & $3.11(1.09)$ & $0.24(0.56)$ & 15.0 & 0.000 \\
\hline $\begin{array}{l}\text { Post-test three months } \\
\text { after the program }\end{array}$ & 3.85 (1.97) & $0.18(0.46)$ & 15.0 & 0.000 \\
\hline \multicolumn{5}{|l|}{ Capacity to take action } \\
\hline Baseline & $0.59(1.18)$ & $0.67(0.65)$ & 429.0 & 0.059 \\
\hline $\begin{array}{l}\text { Post-test at the end of the } \\
\text { program }\end{array}$ & $4.97(2.18)$ & $1.24(1.20)$ & 64.5 & 0.000 \\
\hline $\begin{array}{l}\text { Post-test three months } \\
\text { after the program }\end{array}$ & $6.41(2.61)$ & $1.51(1.12)$ & 19.5 & 0.000 \\
\hline \multicolumn{5}{|c|}{ Community capacity to analyze and manage risks } \\
\hline Baseline & $0.47(1.02)$ & $0.21(0.70)$ & 496.0 & 0.188 \\
\hline $\begin{array}{l}\text { Post-test at the end of the } \\
\text { program }\end{array}$ & $3.76(1.50)$ & $0.21(0.70)$ & 20.5 & 0.000 \\
\hline $\begin{array}{l}\text { Post-test three months } \\
\text { after the program }\end{array}$ & $4.44(1.83)$ & $0.12(0.48)$ & 3.0 & 0.000 \\
\hline \multicolumn{5}{|c|}{ Community capacity to manage risks associated with diabetes } \\
\hline Baseline & $0.26(0.67)$ & $0.24(0.66)$ & 536.0 & 0.613 \\
\hline $\begin{array}{l}\text { Post-test at the end of the } \\
\text { program }\end{array}$ & $3.97(2.25)$ & $0.24(0.66)$ & 53.0 & 0.000 \\
\hline $\begin{array}{l}\text { Post-test three months } \\
\text { after the program }\end{array}$ & $4.91(2.76)$ & $0.24(0.66)$ & 30.0 & 0.000 \\
\hline
\end{tabular}




\begin{tabular}{|c|c|c|c|c|}
\hline \multirow[t]{2}{*}{ Measurement } & \multicolumn{2}{|c|}{$\begin{array}{l}\text { Mean score } \\
(\text { mean rank })\end{array}$} & \multirow{2}{*}{$\begin{array}{l}\text { Mann- } \\
\text { Whitney } \\
\text { U Value }\end{array}$} & \multirow[t]{2}{*}{$p$-value } \\
\hline & Experimental & Control & & \\
\hline \multicolumn{5}{|c|}{ Communication and exchanges with outsiders } \\
\hline Baseline & $0.09(0.38)$ & $0.00(0.00)$ & 528.0 & 0.160 \\
\hline $\begin{array}{l}\text { Post-test at the end of the } \\
\text { program }\end{array}$ & $2.44(1.21)$ & $0.00(0.00)$ & 66.0 & 0.000 \\
\hline $\begin{array}{l}\text { Post-test three months } \\
\text { after the program }\end{array}$ & $3.29(1.83)$ & $0.00(0.00)$ & 33.0 & 0.000 \\
\hline \multicolumn{5}{|l|}{ Individual capacity } \\
\hline Baseline & $0.79(0.95)$ & $0.52(1.00)$ & 441.5 & 0.083 \\
\hline $\begin{array}{l}\text { Post-test at the end of the } \\
\text { program }\end{array}$ & $4.06(1.63)$ & $0.55(0.94)$ & 32.0 & 0.000 \\
\hline $\begin{array}{l}\text { Post-test three months } \\
\text { after the program }\end{array}$ & $5.47(2.22)$ & $0.36(0.74)$ & 8.5 & 0.000 \\
\hline \multicolumn{5}{|l|}{ Total community capacity } \\
\hline Baseline & $5.44(4.10)$ & $5.45(2.80)$ & 521.0 & 0.613 \\
\hline $\begin{array}{l}\text { Post-test at the end of the } \\
\text { program }\end{array}$ & $39.5(14.87)$ & $6.85(2.88)$ & 0 & 0.000 \\
\hline $\begin{array}{l}\text { Post-test three months } \\
\text { after the program }\end{array}$ & $48.65(14.30)$ & $6.73(3.04)$ & 0 & 0.000 \\
\hline
\end{tabular}

\section{DISCUSSION}

This study involved a quasi-experimental design that aimed to examine the effects of a community empowerment program on community awareness and community capacity among stakeholders in diabetes prevention in Buddhist monks.

In terms of awareness, as measured through the CADS, the scores for diabetes awareness itself (diabetes knowledge, prevalence, risk factors, and complication) did not differ between the experimental and control groups post-intervention program. This is not surprising, as the participants were likely already familiar with much of the information about diabetes, risk factors, and complications from their own health education and experiences; diabetes in Buddhist monks is no different than in non-monks. However, the scores of the role of the community in diabetes prevention among Buddhist monks in the experimental group were significantly higher $(p<0.01)$ than the control group. This is probably because the experimental group received the teaching content provided about the role of the community in diabetes prevention among Buddhist monks, knowledge which was new to them. The content of the program involves practical activities that are engaging and provide a platform for participants to work closely with Buddhist monks. The program, therefore, allowed them to explore and reflect on the important 
issues around the health of Buddhist monks in their community. Moreover, the effectiveness of the teaching media had already been established through the Healthy Monks Healthy Nutrition Project, with ineffective activities already weeded out of the program. Importantly, the Healthy Monks Healthy Nutrition Media facilitates information exchange between stakeholders, community members, and the monks aiming to reduce misconceptions concerning food offerings to Buddhist monks. The media focused on the importance of providing healthy food to the monks as the paramount priority, not food that the alms givers think will bring good fortune or that was a favorite of ancestors. Three months after the program, the scores no longer differed, indicating more may need to be done to ensure the long-term effectiveness of the awareness program.

Unlike awareness, community capacity showed significant improvement in the experimental group compared to the control group across all variables, not only immediately after the program, but also three months later. The program was a success because it provided a structured process involving the identification of the health problem, enabled the finding of solutions to the problems, and facilitated the implementation of strategies to help solve the health problems among Buddhist monks, along with building individual capacity of community members based on their knowledge and experience in diabetes prevention among Buddhist monks.
In terms of the components of CCDPS, the community empowerment program built individual capacity within the participants to help prevent diabetes among Buddhist monks ( $p<$ 0.01 ). The community empowerment program promoted the development of interpersonal and social skills in participants, resulting in the linking of community and community organizations through the capacity for action and social support in diabetes prevention among Buddhist monks. Laverack and Wallerstein (2001) stated that empowerment builds individual capacity through the sharing of issues or concerns, and promotes a sense of working as a group and involvement in community activities. Individual capacity can be developed as a result of small group activities, organizational structures, and links with outsiders, together with an increased awareness of the social causes of their disempowerment (Laverack \& Wallerstein, 2001).

The community empowerment program was successful in building capacity of the community organization $(p<0.01)$ and good internal functioning $(p<0.01)$. The effectiveness in building community organization is due to the program strengthening existing organizations, such as the Health Promoting Hospital, the Headman organization, and the Village Health Volunteers organization, which provide training skills and knowledge in diabetes prevention among Buddhist monks. Chaskin et al. (2001) stated that strengthening existing organizations establishes sustainable skills, increases 
knowledge and develops systems and other forms of support that can improve organizational effectiveness over time. In addition, the program encouraged participants to increase their functionality, create a role and develop a sense of responsibility, and create a monitoring and evaluation system for diabetes prevention in Buddhist monks. Role, functionality, and responsibility were important concepts discussed by participants, because the role and responsibility of participants are of first importance in clarifying the difference between primary and secondary participants (Laverack \& Wallerstein, 2001; and United Nations Environment Programme, 2015).

The success of community participation $(p<0.01)$ is most likely because most participants were formal and informal community leaders. Although the participants were recruited based on simple random sampling, they were all respected in their community. The formal leaders can provide new perspectives to their communities to achieve strategic goals and community initiatives. Informal leaders may be more accepting of criticism or direction when they receive guidance from someone of their social status that they respect and trust. Another reason for the success of the program was that participants were encouraged to participate actively. Downing et al. (2009) revealed that community participation is a vehicle for influencing decisions that affect citizens. In addition, the excellent retention rate contributed to the success of the project; the participants indicated this was largely due to being allowed to choose the timing and place of the program (Rebori, 2007). This flexibility was included in the study design on purpose, in recognition of the various demands on participants' time.

Part of the success in the capacity to analyze and plan section $(p<0.01)$ in the experimental group could be attributed to the activities of the community empowerment program that guided the participants to work together to analyze and plan methods for addressing diabetes prevention among Buddhist monks. The photo-voice method helped participants identify problems, analyze, and plan how to enhance food offerings and physical activities among Buddhist monks through a specific photographic technique (Wang \& Burris, 1997). The small-group discussions that followed the photo-voice interventions reflected community concerns and enabled the participants to better analyze the issues and create a care plan to manage the risks associated with diabetes to enhance community capacity in diabetes prevention among Buddhist monks.

The effectiveness in social action $(p<0.01)$ was mainly due to the site visits, when participants met with Buddhist monks; these visits helped change health determinants and provide a supportive environment to sustain diabetes prevention among Buddhist monks. During these visits, participants helped the monks create individual diabetes care plans. The plans required collaboration between the monks and their communities, and helped the monks make healthy choices from the 
offerings they received, while likewise encouraged the community to provide healthier foods in their offerings, such as low fat milk and yogurt, which are high in protein and low in sugar. Participants monitored the weight of Buddhist monks and discussed eating habits, encouraging them to eat a balanced diet. The community participants also encouraged the monks to exercise appropriately. In addition to the visits, participants created media resources related to healthy food offerings for monks, as well as worked with the lay leaders to develop a series of health education classes for novice monks. Evidence has suggested that working collaboratively with the community can promote environmental change and change individual lifestyles and behaviors, as well as help people acquire the skills needed to work independently to improve community health (Lavery et al., 2005).

\section{CONCLUSION}

The objective of the study was to examine the effects of a community empowerment program on community awareness and capacity in diabetes prevention among Buddhist monks based on a quasi-experimental design, pre-test/post-test control group design. The community empowerment program was effective in increasing community awareness and capacity in diabetes prevention among Buddhist monks. As this program was tested in only one district in northern Thailand, generalizations to other parts of Thailand may be limited, as health and education levels are not comparable. The community empowerment program developed here should be tested in other communities and regions of Thailand, to see if similar effects can be achieved. If so, the program should be more widely adopted in communities to help reduce the risk of diabetes in Buddhist monks. From our study, it was evident that including the monks in the program was important and effective for helping increase community capacity in diabetes prevention among the monks themselves. This has a potential added benefit - the monks, as role models in the community, can pass on what is learned to other community members that may be at risk of diabetes.

\section{ACKNOWLEDGMENTS}

We would like to thank the Thailand Research Fund and Chiang Mai University, Thailand, for their grant support for this study. We would also like to thank Associate Professor Dr. Jongjit Angkatavanich for her generous permission to use the various teaching media from the Healthy Monks Healthy Nutrition projects.

\section{REFERENCES}

Africare. (2007). Guidance: How to measure the Food Security Community Capacity Index (FSCCI). Africare Food Security Review, 2.

Al-Khawaldeh, O.A., \& Al-Jaradeen, N. (2013). Diabetes awareness and diabetes risk reduction behaviors among attendance of primary healthcare centers. Diabetes and Metabolic Syndrome: Clinical Research and Reviews, 7(3), 172-178. 
Anderson, R.M., \& Funnell, M.M. (2010). Patient empowerment: myths and misconceptions. Patient Education and Counseling, 79(3), 277-282.

Angkatavanich, J. (2012). Healthy monk and healthy nutrition. Retrieved from http://www.research.chula. ac.th/web/cu_online/2555/ vol_25_01.html

Angkatavanich, J., Ariyapitipun, T., Wisestrith, W., Prasobtham, J., \& Punpanich, D. (2016). Nutritional situation among Buddhist monks from Healthy Monks Healthy Nutrition Project. Bangkok: Panyamit Press. Angkatavanich, J., Wisestrith, W., Sangtian, A., \& Somboonkul, P. (2014). The research report on lifestyle, characteristic, diet, nutrition of monks, Buddhist novice and lay people in four regions, Thailand. Bangkok: Choraka Press.

Bank of Thailand. (2017) Retrieved from https:/www.bot.or.th/english/ statistics/financialmarkets/exchangerate/_layouts/application/exchangerate/exchangerate.aspx

Braun, K.L., Ichiho, H.M., Kuhaulua, R.L., Aitaoto, N.T., Tsark, J.U., Spegal, R., \& Lamb, B.M. (2003). Empowerment through community building: Diabetes today in the Pacific. Journal of Public Health Management and Practice, 9, S19-S25.

Buates, D., Chantachon, S., Paengsoi, K., \& Kanggrang, A. (2010). Monks' health: Holistic Health Care Model by community participation. Journal of Social Science, 6(3), 478-483.
Burns, N., \& Grove, S.K. (2005). The practice of nursing research: Conduct, Ocritique, \& utilization. St. Louis, MO: Elsevier.

Chaskin, R.J., Brown, P., Venkatesh, S., \& Vidal, A. (2001). Building community capacity. New York: Walter de Gruyter.

Downing, D., Covington, M.M., Purchase, H.C., Richard E.M., Du, Y., Fraser, H., ... Bathgate, T. (2009). Four different approaches to community participation. Library and Information Science Research, 13(2), 177-188.

Glenton, C., Scheel, I.B., Pradhan, S., Lewin, S., Hodgins, S., \& Shrestha, V. (2010). The female community health volunteer programme in Nepal: decision makers' perceptions of volunteerism, payment and other incentives. Social Science \& Medicine, 70(12), 1920-1927.

Kuramasuwan, B., Howteerakul, N., Suwannapong, N., \& Rawdaree, P. (2013). Diabetes, impaired fasting glucose, daily life activities, food and beverage consumption among Buddhist monks in Chanthaburi Province, Thailand. International Journal of Diabetes in Developing Countries, 33(1), 23-28. https:// doi.org/10.1007/s13410-0120094

Larpthananon, P. (2013). Health and wellbeing of Thai monks in 2012. Social Research Instutute. Bangkok: Charan Sanit Wong Printing. 
Larpthananon, P. (2014). Healthy nutrition practice for healthy monks. Social Research Instutute. Bangkok: Charan Sanit Wong Printing.

Laverack, G., \& Wallerstein, N. (2001). Measuring community empowerment: A fresh look at organizational domains. Health Promotion International, 16(2), 179-185.

Lavery, S.H., Smith, M.L., Esparza, A.A., Hrushow, A., Moore, M., \& Reed, D.F. (2005). The community action model: A community-driven model designed to address disparities in health. American Journal of Public Health, 95(4), 611-616. https://doi.org/10.2105/AJPH. 2004.047704

Polit, D.F., \& Beck, C.T. (2004). Nursing research: Principles and methods. Lippincott Williams \& Wilkins.

Ramsden, V.R., Osborne, C., Turner, S., \& White, H. (2006). Chapter 6: Building community capacity. In Guiding facilitation in the Canadian context: Enhancing primary health care (pp. 46-57). Canada: Department of Health and Community Services, Newfoundland and Labrador.

Rebori, M.K. (2007). How to organize and run effective meetings. Retrieved from https://www.unce.unr.edu/ publications/files/cd/other/fs 9729.pdf

Rissel, C. (1994). Empowerment: The holy grail of health promotion? Health Promotion International, 9(1), 39-47.
Seibert, S.E., Kraimer, M.L., \& Liden, R.C. (2001). A social capital theory of career success. Academy of Management Journal, 44(2), 219237.

Srimanee, S., Mantawangkul, C., Phumrittikul, P., Chancharoen, K., Hongkrilert, N., \& Romnukul, N. (2013). Factors related to nutrition consumption behaviors of monks and foodstuff dedication behaviors to the Buddhist monks of people in Pasi Charoen District, Bangkok. Research Center for Community Development, Siam University, Thailand.

United Nations Environment Programme. (2015). Awareness and preparedness for emergencies at local level: A process for improving community awareness and preparedness for technological hazards and environmental emergencies. Retrieved from http:// reliefweb.int/sites/reliefweb.int/ files/resources/APELLHandbook 2nd_ed.pdf

Viwatwongkasem, C. (1994). Sample size determination for researches. Thai Journal of Health Research, 8(2), 121-146.

Wang, C., \& Burris, M.A. (1997). Photovoice: Concept, methodology, and use for participatory needs assessment. Health Education \& Behavior, 24(3), 369-387.

Yamaoka, K., \& Tango, T. (2005). Efficacy of lifestyle education to prevent type 2 diabetes: A metaanalysis of randomized controlled trials. Diabetes Care, 28(11), 27802786. 